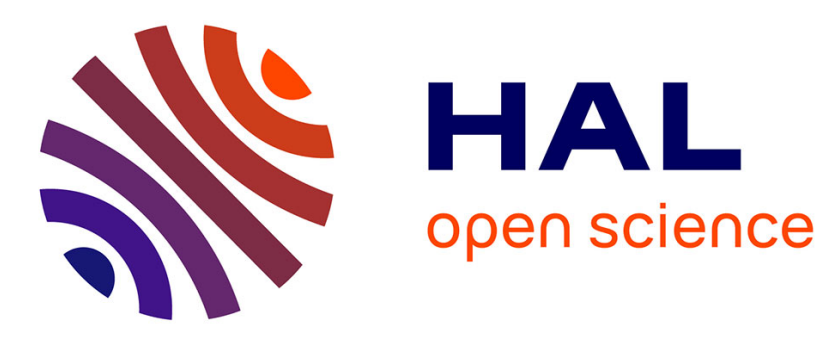

\title{
Problem Solving in France: Research and Curricular Perspectives
}

\author{
Artigue Michèle, Catherine Houdement
}

\section{To cite this version:}

Artigue Michèle, Catherine Houdement. Problem Solving in France: Research and Curricular Perspectives. Zentralblatt für Didaktik der Mathematik, 2007, 39 (5-6), pp.365-382. 10.1007/s11858007-0048-x . hal-03198382

\section{HAL Id: hal-03198382 \\ https://hal.science/hal-03198382}

Submitted on 11 May 2021

HAL is a multi-disciplinary open access archive for the deposit and dissemination of scientific research documents, whether they are published or not. The documents may come from teaching and research institutions in France or abroad, or from public or private research centers.
L'archive ouverte pluridisciplinaire HAL, est destinée au dépôt et à la diffusion de documents scientifiques de niveau recherche, publiés ou non, émanant des établissements d'enseignement et de recherche français ou étrangers, des laboratoires publics ou privés. 
Version auteur

Authors: Michèle Artigue, Catherine Houdement

Title: Problem Solving in France: Research and Curricular Perspectives

Exact reference :

Artigue, M., \& Houdement, C. (2007). Problem Solving in France: Research and Curricular Perspectives. Zentral Blatt für Didaktik der Mathematik, 39. 5-6, 365-382. 


\title{
Problem Solving in France: \\ Didactic and Curricular Perspectives
}

\begin{abstract}
:
In this paper, we address the issue of problem solving in France through two different and complementary approaches, looking both at didactic research and at curricular choices. These two approaches correspond to two different, but not independent perspectives on problem solving and we investigate the existing links between them. We show that in both didactic research and curricular choices, the solving of problems is given a central role in France, but that problem solving, as generally understood, is an object of controversial positions, and we try to elucidate the rationale behind such positions.

This paper is structured in two main parts: the first devoted to didactic research, the second to curricula. In the last discussion part, we question didactic research and curricula as regards their potential for influencing the reality of problem solving in classroom practices.
\end{abstract}

\section{Problem solving in French didactic research}

In French didactic research, contrary to what is the case in many countries, there does not exist a tradition of educational research on problem solving, even if the pioneering work in that area of mathematicians such as Polya (Polya, 1945) and educational researchers such as Schoenfeld (Schoenfeld, 1985, 1992) is well known and valued. In our opinion, this characteristic of French didactic research partially results from the role given to mathematical problems and problem solving in two theoretical frames very influential in that research: the theory of didactic situations (TDS in the following) initiated by Brousseau (see (Brousseau, 1997) and (Warfield, 2006) ${ }^{1}$ for reference texts in English) on the one hand, the anthropological theory of didactics (ATD in the following) initiated by Chevallard (Chevallard, 1992, 1999, 2002) on the other hand. We analyse this role in the two next paragraphs.

\section{I.1. Problem solving in the TDS}

TDS is a theory that Brousseau began to develop in the sixties. Since that time it has progressively enriched (Perrin-Glorian, 1994) for becoming the complex object it is now. It is impossible to present its fundamental ideas and concepts in a few lines, and we invite the reader who is not familiar with this theory to read the first chapter of (Warfield, 2006). In this theory, the fundamental object is the notion of situation initially defined as a system of relationships between some students, a teacher, and some mathematical knowledge. Students' learning results from interactions taking place within such systems and is highly dependent on the characteristics of these. The theory aims at understanding these dependences and at determining conditions for an optimal functioning of these.

\footnotetext{
${ }^{1}$ This text entitled "Invitation to Didactique", accessible on the web, is a very clear introduction to the TDS, Its first chapter includes all the notions mentioned in this article.
} 
Mathematical problems play a fundamental role in the TDS. That mathematical knowledge emerges from the solving of mathematical problems is a epistemological assumption underlying the theory. What kind of mathematical problems? The conditions these are asked to satisfy, as expressed for instance by Brousseau (2006), make clear that problem solving in the TDS is necessarily embedded in the process of learning some particular piece of mathematical knowledge, and that the mathematics to be learnt has to provide optimal solutions to these problems. Conditions also try to ensure that students, with their mathematical background and in ordinary classroom conditions, can experience by themselves this optimality and through it the reasons underlying mathematical conceptualizations. Hence for instance the role played in the TDS by the notion of fundamental situation ${ }^{2}$ linked to the constructs of adidactic situation ${ }^{3}$ and milieu $^{4}$, and the energy devoted by researchers to the identification of such situations.

More precisely, according to Brousseau (2006, p.2): "the notion of situation includes, extends, enlarges and diversifies the notion of problem". Any problem set up in a classroom is explicitly or implicitly part of a situation, and the situation is considered the minimal unit of analysis for understanding what could be or is actually at stake from a cognitive point of view in the solving process.

In the TDS, mathematical knowledge is attributed to different functions to which are attached three categories of situations: situations of action, of communication and of validation. It emerges first as means for action through models that can remain implicit, but it cannot develop without the building of an appropriate language (here the term language has to be understood with a very wide sense), and has then to become part of a fully coherent body of knowledge. These different steps rely, according to the TDS, on different dialectics: dialectics of action, formulation and validation, which require, in order to become effective, different organizations of the students' relationship with mathematical knowledge, that is to say different kinds of situations. Hence the three categories mentioned above. In (Brousseau, 1997), the first chapter beautifully illustrates this theoretical construction through the analysis of a paradigmatic example: "The race to 20" (for a less technical description, see also (Warfield, 2006, p.19-21)). An important point is that, according to Brousseau, significant mathematical learning cannot be achieved if the solving of the problem is too much dependent on the teacher. This basic assumption is embedded in the TDS through the notions of devolution and milieu, as well as through the duality between adidactical and didactical situations. In adidactical situations, students are expected to be able to test, reject, progressively adapt and refine their models and solutions thanks to the potential offered by the milieu of the situation in terms of action and feedback, without relying on the teacher's guidance, without trying to guess the teacher's expectations. A real classroom situation can generally be modelled as a complex intertwining of adidactical and didactical episodes.

As stressed above, problems in the TDS are not isolated problems, they are attached to the progression of knowledge in a given mathematical area, and their solving does not aim at the development of general solving skills or metacognitive competences. Metacognition is often associated in Brousseau's texts to the idea of metacognitive shift, which labels one of the

\footnotetext{
${ }^{2}$ According to the TDS, "each item of mathematical knowledge can be characterized by a (or some) adidactical situation(s) which preserve(s) meaning". These are called fundamental situations (Brousseau 1997, p. 30).

${ }^{3}$ The term adidactic labels a situation where the students behave as epistemic subjects: they forget at least for a while that the problem proposed to them has been designed by the teacher with a particular didactical goal, and accept the mathematical responsibility given to them by the teacher (devolution process).

${ }^{4}$ The adidactic milieu denotes the elements with which the students interact in an adidactic situation. It includes material and symbolic artefacts, and generally other students.
} 
paradoxes of the didactic contract ${ }^{5}$, and is thus negatively connoted. As explained in Brousseau (1997, p. 26), "when a teaching activity has failed, the teacher can feel compelled to justify him/herself and, in order to continue his/her activity, take his/her own formulations and heuristic means as objects of study in place of genuine mathematical knowledge". This phenomena is what Brousseau calls a metacognitive shift. In the same article, he uses as an illustrative case the teaching of set theory during the New Math period, pointing out that "the more the teaching activity produced comments and conventions, the less the students could control the situations which were being put to them." (ibidem, p.27). Moreover, one can find in texts by close colleagues of him (for instance (Sarrazy, 1997)) virulent criticisms against curricular evolutions aiming at the development of general problem solving abilities, and more globally against any type of "meta" perspective in the didactic field.

\section{I.2. Problem solving in the ATD}

The second theory we will evoke in this article: ATD, took this name in the early nineties but it can be seen as an extension of the theory of didactic transposition that Chevallard began to develop in the early eighties, as shown in (Bosch \& Gascon, 2006). In this theory, the fundamental object is the notion of institution, which has to be understood with a very wide meaning. Mathematical activity is considered as a human activity among others taking place in institutions and it is modelled as other human activities in terms of praxeologies. As explained in (Chevallard, 2006, p. 23), praxeologies have both a practical and a theoretical part:

"One can analyse any human doing into two main, interrelated components: praxis, i.e. the practical part, on the one hand, and logos, on the other hand [...] No human action can exist without being, at least partially, "explained", made "intelligible", "justified", "accounted for", in whatever style of "reasoning" such an explanation or justification may be cast. Praxis thus entails logos which in turns backs up praxis."

This duality reflects in mathematical praxeologies Chevallard (1999). The theory considers that, inside institutions, mathematical knowledge emerges both from the solving of types of tasks and the associated development of techniques (the praxis part) and from the accompanying development of a discourse explaining and justifying the techniques used (called technology), technologies being then explained and justified themselves by theories (the logos part). This makes the 4-uplet structure of mathematical praxeologies.

The solving of mathematical problems is thus something essential in the ATD, but it is approached through an institutional perspective, which gives to the analysis a different scope, when comparing to the TDS. As pointed out in Bosch, Chevallard and Gascon (2005, p. 1258):

"problems constitute the origin, the motor, of the process of producing mathematical praxeologies. However, doing mathematics does not only consist in solving problems. [...] Doing mathematics consists in trying to solve a problematic question using previously available techniques and theoretical elements in order to elaborate new ways of doing, new explanations and new justifications of these ways of doing."

In this theoretical approach, initial questions or problems would have to show the reasons for the existence of mathematical praxeologies, and Chevallard (2006) strongly criticizes what he calls the current "monumentalistic" school epistemology which cuts praxeologies from their roots transforming these into monuments that students are asked to visit. To this

\footnotetext{
${ }^{5}$ The didactic contract denotes the implicit set of expectations that the teacher and the students have of each other regarding mathematical knowledge. The progression of knowledge necessarily involves ruptures and renegotiations of the didactic contract.
} 
epistemology, he proposes to substitute a new epistemology based on the notion of study \& research programme, structured around the will to bring an answer to some generating question, taking of course into account the constraints imposed by the institutional context. As is the case in the TDS, problems are not to be considered in an isolated way, and a particular attention is paid to the way praxeologies progressively enlarge their scope and structure, being first pointwise, then local, then regional, then global (Chevallard, 2002), (Bosch, Fonseca and Gascón, 2004), but there is not the same emphasis as in the TDS on the fact that problems have to be chosen and framed in order to present a strong adidactic potential.

Once more, usual views on problem solving are criticized if not directly by Chevallard at least by some close colleagues. The vision that ATD develops about problem solving research is for instance rather well illustrated in Gascón's texts devoted to algebra (Gascón, 1993) or to the epistemological analysis of the evolution of research in mathematics education (Gascón, 1998). According to him, problem solving research mainly situates within what he calls "the classical perspective", which sees learning processes in mathematics as psycho-cognitive processes and whose theoretical references are mainly attached to cognitive sciences; such a view presents evident limitations that the TDS and the ATD have contributed to overcome through the amplification of the didactic problematics they have offered. Recently, the same group of researchers has tried to tackle issues ordinary linked to metacognition with the conceptual tools offered by the ATD, and provide evidence up to what point such an approach changes the usual perspective about these issues (Rodriguez, Bosch and Gascón, 2007).

\section{I.3. Discussion and comments}

In this analysis of the French research perspectives about problem solving, we have up to now focused on two influential theoretical frames: TDS and ATD, but we cannot ignore the role played in French didactic research by a third perspective: the theory of conceptual fields developed by Vergnaud (Vergnaud, 1990). This theory situates within a cognitive perspective and thus could be a priori considered closer to the problem solving research, but once more what is focused on is not the development of problem solving abilities in the usual sense. What is central as regards mathematical problems in this approach is the way these can be organized into classes inside a given conceptual field, such as the field of additive or multiplicative structures, according to the mathematical objects and relations at stake, and the type of reasoning required from students. Addition and subtraction problems involving three data are for instance classified into six different classes: union or comparison of two states, positive or negative transformation of a state into another, and so on. Such a classification aims at understanding their respective difficulties and the possible progression of knowledge in the conceptual field.

There is no doubt that these positions have strongly influenced French didactic research. Research that could more or less be connected with problem solving perspectives or metacognition has maintained in a marginal position, as evidenced by a review of the issues of the journal Recherches en Didactique des Mathématiques from 1980 until now. Moreover, this research has developed rather original perspectives when compared to the usual research on problem solving or metacognition due to the cultural context it was embedded in. This is the case for the research carried out about the idea of meta lever by Robert and her colleagues (Robert and Robinet, 1996). The analysis of students' difficulties with the formal concepts of linear algebra, the difficulties met at building situations making these concepts appear as optimal solutions to problems meaningful for the students (in other words at finding fundamental situations) led these researchers to hypothesize that for some categories of 
mathematical concepts, qualified as $\mathrm{FUG}^{6}$ concepts, a meta perspective must be introduced. This led to the design of original didactic engineering as illustrated in (Dorier, 2000). The same originality can be found in the research which has been developing around Grenier and Payan for about two decades on the didactic use of research problems in discrete mathematics for working on mathematical definitions and proofs (Grenier and Payan, 1998, 2002), (Ouvrier-Buffet, 2003), and is now attached to the project "Maths à Modeler"" .

In the next part we examine up to what point these research positions or other sources have influenced the French mathematics curricula.

\section{Problem solving in the French curricula}

\section{II.1 Introduction}

The French citizen of 2007 is certainly convinced that learning and doing mathematics includes the solving of mathematical problems, especially as a way of testing or reinvesting what has been learnt. This role given to problems is not something new, and as will be illustrated below, and can be traced in the curricular history. What is certainly more recent and denotes an evident evolution in the role given to problems from the first grades is the fact that problems permeate now the different moments of the educational time, from the beginning of the learning process to its end, and are asked not only to attest the appropriation of mathematical knowledge but also to motivate the need for this knowledge and make its learning meaningful.

Seeing the solving of problems in some sense as the source and goal of mathematical learning seems a consensual position in the current curricular documents for compulsory education (from grade 1 to grade 10 , see table 1 below).

\section{Insert Table 1}

This is illustrated by the following two excerpts, coming respectively from the general introduction of the mathematics curriculum for primary school and "Collège" (MEN 2005). Similar comments can be found in official texts for "Lycées".

"A central place for problem solving:

The solving of problems is the main criteria for knowledge mastering in all mathematical domains, but it is also the way for ensuring a meaningful appropriation of this knowledge. From the early stages, mathematics have to be perceived, and thus experienced as something giving tools to anticipate, foresee and decide. Doing mathematics is building such tools which make it possible to solve genuine problems; it is then trying to better understand these tools and training oneself in order to make them operational for the solving of new problems. Theses tools will evolve at "college" level, and other tools will become necessary to solve more and more complex problems."

"The comprehension and the appropriation of mathematical knowledge rely on each student's activity, which must be thus privileged. For that purpose, when possible, situations

\footnotetext{
${ }^{6}$ FUG concepts are defined as Formalizing, Unifying and Generalizing concepts.

${ }^{7}$ Information about this project can be found in its website : http://mathsamodeler.net/

${ }^{8}$ The use of the world "tool" in this excerpt can be linked to the distinction introduced by Douady (Douady, 1986) between the tool and object dimensions of mathematics concepts and the fact that most concepts appear first as implicit tools of mathematical activity before becoming official objects of the mathematics edifice. On the basis of this epistemological analysis, Douady has built a didactical construction known as the tool-object dialectics that many French researchers use jointly with the TDS.
} 
are chosen which create a problem whose solution needs "tools", that is already known techniques or notions, with the aim of achieving the discovering or assimilation of new notions. When these are well mastered, they become new "tools" opening ways towards better or different knowledge. Knowledge can thus make sense for the student from questions he/she asks and from problems he/she solves." (...) "If the solving of problems allows the establishment of new knowledge, it is also a privileged way for enlarging its meaning and ensuring its mastery. For this purpose, more open situations in which students have to mobilise previously learnt knowledge in an autonomous way play an important role."

How has such a change taken place? Under what influence? These are the questions we want to address now, focusing on the evolution of the mathematics syllabus for primary schools over the last 50 years. We begin by a descriptive part before discussing possible influences.

\section{2. The "life" of problems in the French syllabus for primary school}

In French primary schools, the mathematics syllabus has been modified several times during the last fifty years: 1945, 1970, 1977, 1985, 1991, 1995, 2002. These modifications were often but not necessarily linked to more important curricular or societal changes such as those linked to the end of the second world war in 1945, the New Math period in 1970, or the introduction of cycles I to III covering kinder-garden (age: 3 to 6) and elementary school in 1991. Some of the syllabus changes are rather radical as for instance the one implementing the New Math reform in 1970, or the following one expressing a rejection of the new math values and a back to basis movement. Other changes and especially the recent ones can be more adequately described as regulation processes.

For identifying the respective positions that these syllabuses develop about problem solving, and understanding the rationale for these, we decided to cross four different entries: language, didactical functionality, time, methodology. Through the language entry, we try to approach the evolution of positions through the evolution of the language associated with problems, and especially the respective use made of the words problem, situation and situation problem, which appeared to us quite insightful. Through the didactical functionality entry, we try to approach the exact educational role given to the solving of problems in the learning process. Through the time entry, not independent on the previous one, we approach the position given to problem solving in the teaching process. Through the last methodology entry finally, we complement the understanding provided by the other categories, using the information that the syllabus gives about the practical organization of problem solving.

\section{II.2.1 After the second world war: the 1945 syllabus}

In the 1945 syllabus, the word problem refers to word-problems tightly connected to the daily life or to professional questions (balancing a budget, preparing an estimate, an invoice, calculating the weight of sugar necessary to cook jam, the area of a field). Problem solving is an individual task serving to test and reinvest in specific contexts taught mathematical knowledge, and also to show students the usefulness of mathematics for their ordinary and professional life. But the problems are phrased in such a way that no contextual knowledge is necessary. They have to be solved by applying taught mathematics (in fact finding the right operations to be performed with the given data) without other real consideration or control. They are essentially numerical problems and their complexity depends on the number of operations involved in finding the result. 


\section{II.2.2 The New Math period: the 1970 syllabus}

The program of 1970, inspired by the New Maths, breaks with this utilitarian vision of the problem solving and mathematics at primary school, considered as an obstacle to mathematical understanding. The word problem disappears from the text of the syllabus but is still present in the comments, associated with the following action: deducing new information from known information. The term situation seems to be preferred to the term problem, but not with the meaning given to it later in the TDS. A situation denotes here a context familiar to the students. Situations are given a double didactical functionality: they serve to "motivate the introduction of new notions" and also to "apply properties or relations previously established by the students". For the first time, methodological elements are included in the syllabus, describing steps in the solving process, such as: "analyze the situation, extricate chains of elementary situations, and schematize them to put in evidence the mathematical relations describing them".

In the implementation of this syllabus, the schematization of situations, and conversely the interpretation of schematizations, using tools such as Venn diagrams or Cartesian tables, took an exaggerated importance, generating drifts pointed out by many didacticians and modeled in terms of metacognitive shift in the TDS, as explained above.

\section{II.2.3 The reaction: from 1977 to 1980}

The rejection of the abstraction of the New Math period revolutionises problem solving with the emergence of a new idea, that of situation-probleme (problem-situation in the following) which appears in the syllabus in 1978 (grades 2 and 3). The new expression is indeed used for supporting the introduction of more open and real problems, potentially a source of many different questions, not only strictly mathematical questions. These questions can generally have many different answers and their solution requires looking for additional information. An example of problem-situation often used at that time is the organization of a school journey, for which the class has to decide, after discussion, the means of transportation, to select schedules and to calculate the corresponding costs, collecting and using for that purpose real data. A problem-situation goes along with, and aims, at some kind of transversal methodological learning: elaboration of questions, search for information and organization of the data collected, validation based on mathematical or pragmatic arguments (that is to say based on effective testing), communication of the answers in an appropriate way (beyond the standard triptych: plan-solution-operation used before). The syllabus makes explicit three different roles given to problem-situations in the learning process: approaching and building new mathematical tools, reinvesting previous experiences, expressing the creative power of ones self and testing reasoning modes (in more complex problem-situations), and also it emphasizes the fact that working on complex problem-situations is not only an individual task.

\section{II.2.4 Regulations: 1985, 1991 and 1995}

The syllabus of 1985, once more, implements a linguistic change: the expression problemsituation disappears from the text of the syllabus, and this disappearance will be definitive ${ }^{9}$. This phenomenon can be considered a posteriori as a regulation phenomenon induced by what is observed in the use of problem-situations, students being given too much freedom in the choice of research directions in very open situations without enough mathematical focuse The three roles given to the solving of problems in the learning process are reaffirmed, the third role being associated with the idea of "real research (for instance, finding all the plane

\footnotetext{
${ }^{9}$ It must be stressed nevertheless that the expression problem-situation will not disappear from the educational discourse and is still used at primary and secondary level.
} 
patterns of a cube)". Moreover, the way the first role is phrased suggests a modification regarding the balance in mathematical responsibility between the student and the teacher in the development of new mathematical knowledge. It is indeed written that "students discover mathematical notions as answers to problems", and not only that problems motivate the introduction of new knowledge. As regards methodological issues, the description present in the previous syllabus gives way to a teaching prescription. Nevertheless, the text of the 1985 syllabus is short and not very explicit as regards the evolution expected.

The syllabus of 1991 incorporates the idea of cycles (a cycle corresponds to 3 years) and complements the syllabus of 1985 with a list of competences to be reached at the end of each cycle. Below is the list of competences which is presented in a specific heading entitled "Résolution de problèmes":

"In diverse situations, the student will be able to:

- recognize, sort out, organize and handle data useful for the solving of a problem;

- formulate and communicate his/her procedure and its results;

- argue about the validity of a solution;

- elaborate an original method in a real research problem, that is to say a problem for which there is, for the moment, no learnt solution;

- elaborate a questioning from a set of data." (Les cycles à l'école primaire, 1991, p. 52)

The 1995 syllabus, which integrates contents from the 1985 syllabus and competences from the 1991 syllabus, reaffirms the central role to be given to problems (including at the beginning of the learning process) and the importance to be devoted to the research process so that the students could really build new knowledge on their former experience. It also proposes to develop specific activities (according to the list of competences given above) to set up methodological competences for problem solving. But looking at the textbooks published at that time, one can see that the most followed prescription is that concerning the development of methodological activities, doubtless because these can be integrated into ordinary practices without great perturbation. These methodological prescriptions and especially the first line of the list of competences listed above gave way in textbooks to activities where the students were asked to underline the useful information or cross out the useless ones in the text of a problem before being asked to solve the problem (and sometimes without being asked to solve it at all), asked to find a mathematical question for a given text. This common drift attracted the attention of various didacticians who pointed out its counterproductive effects. The 2002 syllabus clearly reacts to such drifts.

\section{II.2.5 Reconsidering transversal ambitions: the 2002 syllabus}

The 2002 syllabus does not introduce linguistic changes as regards problem solving but abolishes methodological prescriptions and the competence item: "Recognize, sort out, organize and handle the data useful for the solving of problem". It reaffirms the link existing between problems and mathematical knowledge, whatever is the moment when these are set up, and the interest to have problems upstream the learning process.

The expression "research problem" is kept and these problems are given a double functionality: to allow students to build new knowledge and to place them in a research posture. To these research problems are added problems of simple or more complex application, aiming at the reinvestment of learnt knowledge. Moreover, the relativity of the "research" character of a problem is pointed out in sentences such as the following: "to find how much every child after a fair sharing of 60 candies between 3 children has" is a simple application problem in cycle 3 but a research problem in cycle 2". The official syllabus is complemented by a substantial accompanying document ( 84 pages +95 pages), commenting it and illustrating it through many examples. 


\section{II.2.6 Conclusion}

The reading of the way problems and their solving process are dealt with in the successive syllabuses and accompanying documents for primary school from 1945 to now, shows evident changes. The solving of problems has always been given a substantial role in the syllabus but their nature and role have progressively changed. Just after the Second World War, primary school is given mainly an utilitarian aim, coherent with the fact that for many students, schooling ends with primary school. The role given to problems, the forms they have reflect this utilitarian perspective and the pedagogical perspectives dominant at that time. Placed at the end of the learning process, problems have to show that the goals given to primary education have been reached, that the mathematics knowledge to be transmitted has been effectively transmitted. 25 years later, the situation has radically changed. Primary education does no longer represent the end of schooling and primary education has to prepare secondary education. Mathematical and pedagogical perspectives are also moving. Problems begin to permeate the whole learning process, and being asked to also motivate the learning of new mathematical knowledge, they necessarily change in nature. From the New Math reform to now, several movements intertwine: problems confirm their position at the beginning of the learning process where, progressively, they are not only asked to motivate the introduction of new knowledge but also, when possible, to allow students to discover by themselves the new mathematics to be learnt. Simultaneously one can observe, starting in the late seventies, a second movement associated with the introduction of methodological and more transversal ambitions, supported first by the so-called problem-situations, not necessarily focused on the sole mathematics, then by research activities on open problems. These transversal ambitions become more explicit in the nineties but visibly remain a controversial matter, as shown by the modifications introduced in the last reform. Seen first as an individual activity, problem solving takes also a cooperative dimension from 1977.

How to explain these different movements and for instance the moving positions regarding transversal and methodological abilities in primary syllabuses, not observed at secondary level? What relationships do these movements have with the development of didactic research? Do they express an increasing influence of this research on curricular choice? Do they reflect other influences? These are the questions we discuss in the next part.

\section{II.3 Discussion}

We have chosen to develop this discussion through three successive steps. In the first step, we point out curricular processes directly visible in the history summarized above: regulation phenomena normal in curricular evolutions on the one hand, the increasing influence of didactic research on the other hand. In a second step, we consider the influence of innovation and action-research carried out in the IREMs and at the INRP, which even when linked to didactic research obeys a specific culture, and is less controlled by didactic theories. We also point out the role played by these institutions in the connection between primary and secondary education. Finally, in the last part, returning to primary education, we try to describe how these different influences have contributed to the current curricular position.

\section{II.3.1 Two visible phenomena}

\section{a) Regulation processes}

Some of the evolutions mentioned above can be interpreted as regulation processes trying to correct the negative effects of previous curricular decisions. As already mentioned, the 1977 reform rejects the New Math values and problem-situations. The emphasis that they put on 
real contexts can be seen as a reaction to the formal games on representations generated by the 1970 curriculum. In the same way, the 1985 syllabus reacts to drifts emerging from an uncontrolled use of problem-situations, and the 2002 syllabus reacts to drifts generated by the methodological prescriptions introduced in the previous reform. These methodological prescriptions indeed gave way in many textbooks to a lot of activities, described above without real mathematics intention, and supposing the existence of transferable general solving techniques. Such activities took unreasonable importance in classroom practices, attracting the attention of researchers who pointed out their counterproductive effects, as already mentioned. The changes and clarifications introduced in the 2002 syllabus as regards methodological aspects and the roles to be given to research problems can thus be interpreted as a reaction to these negative effects.

\section{b) An increasing influence of didactic research}

The variation in position of problems in the learning process, and the increasing importance given to them in the emergence of new mathematical knowledge is, for its part, obviously linked, from the beginning, to the development of a didactic reflection inspired by constructivist ideas. From a cognitive point of view, these constructivist perspectives underlie the theory of conceptual fields, the TDS as well as the tool-object dialectics. Along the years, their knowledge increases in the noosphere ${ }^{10}$ (Chevallard, 1985) of the educational system, and they progressively permeate the educational discourse. The change of position of problems in the learning process is thus progressively supported by a vision of the development of mathematical knowledge beginning by the emergence of implicit tools which then become explicit and are studied for themselves, as evidenced by the two excerpts of the official documents quoted at the beginning of this part; such a vision lies at the heart of the tool-object dialectics. The change in the respective responsibilities given to the teacher and the student appearing in the 1985 syllabus, the importance given to the student's action, the attention paid at the building of adequate relationships between ancient and new knowledge in the 1995 syllabus, also denote an evident influence of didactic research. And these didactic influences become progressively more explicit. For instance, in the 2002 syllabus explicit reference is made to the categories of additive and multiplicative problems defined by Vergnaud "(Document d'application Cycle 2 MEN 2002b p.15-16, according to Vergnaud, 1990)", and to the notions of spatial knowledge and situations introduced by Berthelot and Salin in the framework of the TDS "(Espace et géométrie, p. 66-77, MEN 2005, according to Berthelot-Salin, 1998)". Let us notice nevertheless that this explicit reference does not include the use of technical didactical terms such as those used for instance in the part I of this article.

Didactic reflection first developed in the IREMs ${ }^{11}$ (the three first IREMs were created in 1969) and at the INRP ${ }^{12}$, then also in university laboratories as far as didactic research institutionalized. The didactic reflection and research carried out in the IREMs and at the INRP globally developed under the influence of constructivist perspectives, but was

\footnotetext{
${ }^{10}$ The term noosphere denotes the interface between didactic systems stricto sensu, and the outside world. The noosphere involves all those having curricular responsibilities, the authors of textbooks and didactic material, the members of educational commissions and associations...

${ }^{11}$ IREM: Research Institute in Mathematics Education. A national commission created in 1975: the COPIRELEM coordinates the IREMs activities dealing with primary education. It plays a crucial role in the diffusion of research and action-research results, through its annual conferences and seminars, its various publications, its regular contacts with the Ministry of Education, and the involvement of some of its members in governmental groups of experts. Information about the IREMs and the COPIRELEM can be found on the national website of the IREMs: www.irem.univ-mrs.fr

${ }^{12}$ INRP: National Institute for Pedagogical Research.
} 
multiform and most often more spontaneous than the didactic research evoked so far. It was the source of original positions with respect to problem solving that have permeated both primary and secondary mathematics education. We examine these and their curricular influence in the next paragraphs.

\section{II.3.2 Innovation and action-research: the IREM and INRP contribution}

\section{a) The IREMs: From Glaeser's typology to open problems, problem-situations and research narratives}

In France, the New Math reform was accompanied by an important institutional effort devoted to in-service teacher training, and the IREMs played a crucial role in it. In this context, Glaeser who was the first director of the IREM of Strasbourg, inspired by Polya and cognitive theories linked to information processing, published in 1973 a book entitled: Pédagogie de l'exercice et du problème, addressed to secondary mathematics teachers. In this book, he introduced a typology distinguishing between 7 classes of exercises according to their educational goals ${ }^{13}$, illustrating each category by different commented examples. Problems (also called research exercises) constitute one of these categories. Their ambition is to cultivate students' intelligence defined as the ability to cope with new situations and grasp relationships. Glaeser points out that "conversely to exposition exercises, the mathematical content is of little importance in a problem. What is important is to create curiosity, to launch a research behaviour"14 (1976, p.19). Researching on problems is presented by Glaeser as the most important mathematical activity but one page later (p. 20) he writes that "researching on problems is not a school activity compatible with strict schedules, and limited time". For him it can thus only be a very episodic activity in classrooms but, even experienced just a few times, can be a memorable experience.

Following these ideas, several IREM groups tried to create such problems, still for secondary education. Among these, the work carried out in the IREM of Lyon has certainly been the most influential. This IREM published in 1983 a first booklet entitled 250 problems for our students, for Collège level including just problem texts; then it progressively developed experimentations and analysis of the corresponding practices, introducing the expression problème ouvert (open problem in the following) for qualifying these problems. This work resulted in different publications and (Arsac, Germain and Mante, 1988) has become a reference. Open problems are there defined as problems with a short text which induces neither a method nor a solution; their solving does not reduce to the direct application of known results or tools; they situate in a context familiar enough to the students to make the problem meaningful, and allow them to engage in trials, conjectures... (p.7-9). They are used for proposing to students learning situations inducing them to "explore - conjecture - test prove", that is to say, according to the authors, to behave as mathematicians. Emphasis is put on the didactic scenario which has been progressively fixed for making this likely to appear, as experiments have shown that choosing good problems is not enough. This scenario spreads over two classroom sessions: the first session is devoted to small group research after a small time of individual appropriation of the problem, and ends with the preparation of a poster by each group; the second session is devoted to the presentation of the group work and its collective discussion in the form of a scientific debate (Legrand, 1993); the text clarifies the role of the teacher in each of these phases. Reference is made to Glaeser's work, but the

\footnotetext{
${ }^{13}$ These categories are the following : Exercices d'exposition, problèmes ou exercices de recherche, exercices didactiques, exécution de tâches techniques, manipulations, applications des mathématiques, tests.

${ }^{14}$ The quotations come from the second edition of the book published in 1976, much more accessible than the original one.
} 
authors insist on the fact that, conversely to Glaeser, they propose a regular practice of open problems in classrooms.

In this book, the authors also situate this practice with respect to the use of problem-situations for the learning of new notions, as recommended by the "Collège" syllabus of $1985^{15}$, making it clear that they give this polysemic notion a meaning inspired by didactic research, and illustrating it by one example ${ }^{16}$. In fact, with regard to the problems, they refer to the conditions introduced by Douady in the tool-object dialectics: the student can engage in the solving of the problem and perceive what is a possible answer to it, but her knowledge is a priori insufficient for an immediate solution; the student is able to decide if a given answer is or is not a solution; knowledge aimed at must be the best tool for solving the problem for students at this level of schooling; the problem can be formulated in at least two different settings and connections established between them, such connections favouring the construction of new knowledge. As regards the management of the situation, the authors transpose Brousseau's categories, proposing after the devolution of the problem, successive phases of action, formulation, validation and institutionalization, followed by exercises and assessment. Open problems and problem-situations do not thus have the same educational goal, and are not managed the same. With problem-situations, what is aimed at is the construction by the student of new mathematical knowledge, and the influence of the TDS and tool-object dialectics is evident. With open problems, what is important is the process: a research experience including the different facets of mathematical activity from trials and exploration to proof. But it would be false to say that what is aimed at is the development of general problem solving abilities.

The same occurs with another object which has been progressively developed in the IREM community: the research narratives (Chevalier and Sauter, 1992), (Sauter 2000), (Bonafé and al., 2002). Research narratives are based on the solving of open problems, but solving here is an individual process, possibly out of school, and specific emphasis is placed on the narration by the students in natural language of their research process including its dead-ends, and on a collective work on these narratives carefully prepared and orchestrated by the teacher. As with open problems, the emphasis is put on the development of a scientific attitude, but the authors also stress what is specifically offered by these narratives in natural language and how they make accessible to the teacher the richness and singularity of the solving processes. Research narratives are generally used as regular but episodic activities along the school year, and what is assessed is the quality of the research narrative including its reflective part and not the results obtained. This is another characteristic that makes them close to open problems.

All the problem solving practices mentioned in this paragraph first developed at secondary level and were influential at that level ${ }^{17}$. They have progressively influenced the vision developed in French education as regards problem solving even in primary education, especially thanks to the connection between primary and secondary mathematics education established in the IREMs where primary and secondary teachers and teacher trainers work together with university mathematicians. Nevertheless, there is no doubt that what has been

\footnotetext{
${ }^{15}$ In the official syllabus, the expression problem-situation, present in the preparatory texts, has nearly disappeared at the benefit of the expression "situation creating a problem".

${ }^{16}$ This single example contrasts with the rich set of open problems proposed in the book. The part devoted to problem-situations in this book is in fact inspired by a text on learning situations and problem situations published in the first book produced by the Commission Inter-IREM Collège: Suivi scientifique Sixième - 1985 1986 resulting from the pre-experimentation of the new Collège syllabus imparted to the IREMs by the Ministry of Education from 1985 to 1989.

${ }^{17}$ through the IREM publications but also the strong engagement of IREMs in in-service teacher training programmes.
} 
the most influential as regards primary education for a long time has been the work carried out in the ERMEL group at the INRP. We come to that now.

\section{b) INRP: the ERMEL group}

Concerning primary school, from 1972, the INRP developed an important action-research project taken in charge by the ERMEL ${ }^{18}$ team. The first three volumes published from 1977 to 1981 and covering grades 1 to 3 (CP to $\mathrm{CE} 2$ ): Mathématiques à l'Ecole Elémentaire exemplify what could be at the time, according to this group, a "pedagogy of problems at primary school" (1978, page 36, CE). The expression problem-situation is defined there through the educational goals given to such situations, and the influence of cognitive theories of information processes, highly influential at that time in the cognitive field, is evident. There is no doubt that the innovative work developed by ERMEL directly influenced the 1978 syllabus, and the three books mentioned above help understand the rationale underlying this syllabus. What is expressed in these books is the wish to transform the usual close numerical word-problems into more open questions regarding the world, within a pluridisciplinary perspective directly linked to the comprehensive function of the primary school teacher; the wish is also to develop a cooperative activity among the students and to limit the interventions of the teacher. Three more volumes were published in 1981 (ERMEL, Apprentissages Mathématiques à l'Ecole Élémentaire, CE2, CM1, CM2 Hatier). They contrast problemsituation and classic problems "through their contents and their shape and also through the working modalities and the communication which they imply" (p. 33), characterizing the latter by orderly and closed questions structuring the resolution, necessary and sufficient information provided, and affirming, in a rather simplistic way, that through such problems students are just taught "to decode a statement and to look for the knowledge which, in their knowledge base, applies to the problem set up".

How did these first perspectives merge with the development and diffusion of didactic research and theories? We address this question in the next paragraph, focusing on primary education and on the TDS, certainly the most influential didactic theory at this level.

\section{II.3. 3 The intertwining influence of didactic theories and action-research}

In spite of the early foundation of the $\operatorname{COREM}^{19}$ (1974) and the regular publication by the IREM of Bordeaux of booklets devoted to the teaching of mathematics at primary school inspired by the COREM experience, Brousseau's research only began to diffuse in primary education, beyond the community of didacticians, in the mid eighties. The COPIRELEM previously mentioned here played an essential role. For instance, the brochure Situationsproblèmes (Elem-Math IX 1987 edited by the COPIRELEM and published by the APMEP ${ }^{20}$ ) proposed a transposition of the notion of didactic situation, at the heart of the TSD, relying once more on the expression problem-situation already part of the educational language of primary school. This notion of problem-situation does not correspond to that present in the 1977 syllabus and eliminated in 1985; it is neither exactly the same as that mentioned above. Problem-situations are indeed differentiated from classic problems in the following way: a problem-situation does not reduce either to the text of a problem, or to the articulation of this text in the classroom; it also includes the methodology planed by the teacher for organizing its solving in the classroom up to the validation of the solutions (Situations-problèmes, p. 32). It can thus be seen as a problem plus a didactic scenario. The booklet illustrates the notion

\footnotetext{
${ }^{18}$ ERMEL : Equipe de recherche sur l'Enseignement des mathématiques à l'École Élémentaire.

${ }^{19}$ COREM : Centre pour l'Observation et la Recherche sur l'Enseignement des Mathématiques, created by Brousseau and attached to the IREM of Bordeaux.

${ }^{20}$ APMEP : Association des Professeurs de Mathématiques de l'Enseignement Public
} 
through different examples. Some directly come from Brousseau's experiments and research such as the well known situation of the "Puzzle enlargement" 21 (p. 80), or "the Game of the travelers and guides" (p. 83). Nevertheless, the way these examples are dealt with does not reflect the epistemological foundations of the TDS, the importance given to it in the games characteristic of a given piece of knowledge, and to the way the successive games organize the progression of mathematical knowledge, as is the case for instance in the 45 situations of the didactic engineering associated with the teaching of decimal and rational numbers from which the situation of the puzzle enlargement is taken (Brousseau, 1987). These are more frequently treated as contexts providing themes for interesting but isolated mathematics questions and studies. This tendency, for instance, which is especially visible in examples such as the "Phonebook" (Situations-problèmes, p. 37) or the "Treasure search" (ibidem, p. 46), shows that the notion of problem-situation is some kind of hybrid object resulting from different influences and complying with different educational goals and constraints, sensitive to the importance of the didactic environment of problem solving, but rather far from the notions of adidactic and didactic situations of the TDS.

Of course, one can see in the role given to problems in the eighties, as explained in II.2.2, an influence of didactic research and more specifically of the TDS, pointing out the coherence between the educational discourse and Brousseau's words as in the quotation below:

"We assume, then, that the construction of meaning, as we understand it, implies a constant interaction of the student and problem-situations, a dialectical interaction (because the subject anticipates and directs her actions) in which she engages her previous knowings, submit them to revision, modifies them, completes them or rejects them to form new conceptions." (Brousseau, 1997, p. 82-83).

Nevertheless, in our opinion, it is important not to over-estimate the depth of such an influence. Even if some situations such as the "Race to 20" or the "Puzzle enlargement" have seduced teachers and teacher educators by their originality, their potential for motivating students' interesting mathematical activity, becoming in some sense "classics", from the diverse and long term engineering designs developed for primary school in the framework of the TDS, only the general ideas and some particular situations really migrated into the educational texts. Moreover this emphasis on some emblematic situations, generally associated with introductory phases of the learning process, tended to destabilize the balance between the different moments of the teaching process, with the meaning given to this term in the ATD (Chevallard, 1999), the time devoted to the moment of first meeting strongly increasing at the expense of the time devoted to the moments of work of the technique and of institutionalization. But one has to acknowledge that institutionalization processes were paid limited attention in the first texts written about the TDS.

From the eighties, the emphasis put on the role given to problems in the learning process made it necessary to have an educational accompanying of problem solving practices. The INRP built proposals, notably inspired by cognitive visions linked to information processing, which perspired more and more in the programs from 1985 to 1995 . These proposals infiltrated textbooks and tended to transform the guidance of problem solving practices into some rigid protocol independent of mathematics knowledge. They were criticized by several researchers because they supposed the existence of general competences for problem solving independently on the particular mathematics knowledge at stake (Balmes \& Coppé, 1999), (Houdement, 1999), and on the characteristics of solving situations. This last point was especially developed by Sarrazy (1997) previously mentioned who pointed out the incoherence of such an hypothesis with the TDS. The 2002 syllabus obviously attests the impact of these criticisms on the noosphere.

\footnotetext{
${ }^{21}$ This situation is also described in (Warfield, 2006), pages 55-57.
} 
The groups of experts in charge of the writing of the 2002 syllabus for primary school and of the new 2005 syllabus for the Collège could rely on many more research resources than the previous ones, due to the development of didactic research at primary and secondary school in the last decade, both from a theoretical and experimental point of view: research articles such as those published in the journal Recherches en Didactique des Mathématiques, but also texts resulting from a transpositive work from theory to practice, such as those published by the IREM journals: Grand $N$ for primary school, Petit $x$ for the Collège, and Repères IREM, or the publications of the COPIRELEM, or new editions of the ERMEL books such as Apprentissages numériques et résolution de problèmes 1991-1999, which were more directly fed by didactic research. Another important point is that didactic research, which had first focused on students' conceptual development, and on the building and experimentation of engineering designs, had in the last decade, paid an increasing attention to the analysis of teachers' practices and teacher professional development in ordinary classrooms and environments, and to the analysis of the effect of teacher training practices. This certainly explains the decreasing influence in the new primary syllabus of ideas inspired by information processing as regards problem solving, and the more explicit references made to didactic research in the extensive accompanying documents, together with the efforts made to regulate observed drifts in ordinary practices, including those coming from misinterpretations of research results or from simplistic transpositions of theoretical positions. Thus, for instance, the reaffirmed importance of memorization and training, and of the development of computational abilities both written and mental.

\section{II.4 Conclusion}

The analysis, whose main results we have presented in this second part shows, as least as regards primary school, a rather complex landscape. Even if situated within a global constructive perspective since the late seventies, primary mathematics education is submitted to diverse influences. The theories of information processing, highly influential in the seventies and early eighties in the cognitive field worldwide, classical approaches to problem solving as those initiated by Polya are present and their influence is visible in the syllabus from the late seventies until the last reform. Nevertheless they have to face a development of the didactic field which, even in its most psychological component, that of the theory of conceptual field, is especially sensitive to the epistemological analysis of mathematical knowledge, and to the situated character of mathematical conceptualisations and practices, and they have to comply with this development. We also see that the penetration of the visions about problems and problem solving carried out by French didactic research in the syllabus is a long term process, mediated by different institutions, especially INRP and the IREMs. The deepest parts of the theoretical developments neither enter the syllabus nor the accompanying documents, and the didactic penetration gives way to some kind of hybrid objects. The notion of problem-situation is such an object. It is submitted to the theoretical influence of the TDS and the tool-object dialectics but its emergence and evolution obeys a specific logic which is not that of research. It relies on theoretical ideas and principles which echo some important concerns: the need to react against the formal abuses of the new math period first, then the desire to integrate constructivist perspectives and break with ostensive practices, whose evident limits are attested by national tests... but what finally results is an object free from many of the attributes of the notion of situation in the TDS. This object gains meaning not only through the paradigmatic situations borrowed from the theory but also through the wide set of problem-situations which have been designed and used along the years in the IREMs and at the INRP, to complement the restricted set of situations offered by research. What we observe can be seen as a tension between some theoretical didactics and transposed versions of it, transposition processes being all the more important as theoretical 
didactics, in the first stages of its development, is poorly sensitive to the teacher, and to the ecology of the new forms of teaching it proposes.

After describing this complex landscape, we would like to enter in the last and conclusive part of this text into another dimension of the reflection, trying to link research and curricular perspectives to the reality of classroom practices.

\section{From didactic research and intended curriculum to effective practices}

Through the syllabus analysis we have only accessed what is usual called the intended curriculum. What about the implemented curriculum and the effective classroom practices regarding problem solving? Answering in a scientific way such a question is beyond the scope of this text, but we would nevertheless introduce the discussion on this crucial issue, and raise some interesting points.

We have already mentioned some regulation processes evidencing the existence of regular gaps between the intended curricula and the implemented ones. These were generated by the introduction in the syllabus of some kind of transversal aims as regards problem solving, and the resulting emergence of tasks where the specificity of the mathematics discipline, both in its content and practices, were no longer visible.

But the gaps between curricular intentions and effective practices certainly do not limit to this category of phenomena. The ambition of having new mathematics knowledge emerging from the solving of adequate problems, with a substantial responsibility given to the students in the emergence of this new mathematics knowledge is, as everyone knows, something far from being easy, even when research has shown its possibility. Moreover, when such evidence seems to be provided, this is generally in the form of an existence theorem, and the contextual characteristics which make this assertion valid are not given, not even accessible. What ensures the success of this enterprise does not only depend upon local contextual characteristics but needs a much more global and systemic view, both in scope and time, to be understood. Thus the ambition expressed by the syllabus since the early eighties is a very challenging one, and certainly the source of many discrepancies, reinforced in primary schools by the fact that, in France as is the case in many countries, teachers are not mathematics specialists, and quite often not proficient in mathematics, and that the mathematics and didactic formation they receive during their training does not compensate these limitations. The development of research on teachers' practices based on naturalistic observations has proved the difficulties met by teachers at fulfilling these ambitions and has allowed researchers to identify unexpected didactic phenomena resulting from these difficulties (Masselot, 2000), (Vergnes, 2001), (Roditi, 2001). They have increased the researchers' sensitivity to the ecology of their constructions, and to the importance of the teacher's role. There is no doubt that the vision of the teacher initially proposed by the TDS or the dialectique outil-object, for instance, was a much too simplistic one. The promising theoretical elaborations provided by the double-approach ergonomic and didactic (Robert and Rogalski 2002, 2005), by the ATD as well as by recent evolutions of the TDS (Laborde and Perrin-Glorian, 2005) result from the acknowledgment of these difficulties.

Another point is that, rather than relying on the syllabus, teachers tend to rely on the textbook whose choice is their own responsibility. The edition of textbooks being free, there is a multitude of textbook collections (for instance, more than fourteen for primary school) not including those proposed on Websites. This diversity generates a multitude of different interpretations for the syllabus on which teachers do not have enough critical hindsight. All the textbooks propose what is called "preparatory activities" to students before introducing a 
new notion, but the problematic nature of these activities and the way the new notions are expected to emerge from them, varies a lot. They can be introduced in an ostensive way, through a written text, or through a didactic scenario described in a teacher-book associated with the textbook, playing on didactic variables for favoring an adidactic functioning, and guiding the teacher in the management of the devolution and institutionalization phases. The difference between textbooks often results from the quality of the guidance provided in the teacher-books for these preparatory activities.

Let us illustrate this difference through an example: the first meeting with multiplication in CE1 in two different textbooks (cf. appendix). The first one ${ }^{22}$ does not propose a teacherbook. Multiplication appears first in a lesson (p.96) entitled: "From sums to products", in a pure ostensive way, without any kind of problematization. An image shows five post_office cars, each one of them carrying 6 bags of letters, and two numerical expressions are associated with it: $6+6+6+6+6=30$ and $6 \times 5$. Students are asked to do the same with a similar image, then to memorize that an addition of equal numbers can be replaced by a multiplication. Then several exercises involving multiplicative coding of collections presented in rectangular patterns, and conversions from additive to multiplicative expressions and viceversa are proposed. The following lesson asks the student to produce multiplication tables through iterate additions.

The second textbook ${ }^{23}$ includes a teacher textbook. Multiplication is introduced (p.86) in a lesson entitled: "Multiplication" whose goal is presented as: "The solving of problems with reiterated additions". This lesson is commented in the teacher textbook (p.122), which describes a preparatory activity necessary for making sense of what is proposed in the student textbook. In this activity, students are asked to play several times (by groups of two or threes, with a sheet of paper for writing the results) to the game proposed in the textbook. Then a collective phase has to be organized where the different representations used by the students for coding the results and the calculations that are made are presented and discussed. The synthesis of this discussion is expected to allow the articulation of the relationship between a reiterated addition and the dimensions of the coloured part of the corresponding grid, and to support its institutionalization through a multiplicative representation. What is proposed in the student textbook corresponds in fact to the individual reinvestment of this collective game. The next lesson proposes a new activity where students are asked to calculate the quickest as is possible, reiterated additions resulting from the same game with a calculator, which shows the power and the economy of the multiplicative representation when compared to the additive one.

These characteristics of the textbooks and the limited help that most of them provided to primary teachers in giving its expected role to the solving of problems was one of the reasons which has led the group of experts in charge of the 2002 curriculum to complement the official syllabus by a substantial accompanying document. The second author of this text was a member of this group, and experienced the difficulty of integrating usefully results of didactic research in such a document. What can be considered as stable enough in the didactic field for inclusion? How to phrase it in order to make it understandable by ordinary teachers and avoid misunderstandings? What examples to choose in order to illustrate the positions and the recommendations, and how to avoid the trap of isolated examples that has proved so counterproductive? What focus on and how to avoid the creation of an artificial imbalance between the different didactic moments through the focus chosen?

\footnotetext{
${ }^{22}$ Les maths à la découverte du monde CE1 (176 pages). Editions Hachette 2004

23 EuroMaths CE1 student textbook (160 pages), teacher textbook (255 pages). Editions Hatier 2001
} 
This was not at all an easy task and the result is certainly not fully satisfactory ${ }^{24}$. As regards elements of didactic knowledge, it was decided to only consider consensual elements in the community, whose integration could be supported by detailed resources accessible to teachers, as are the COPIRELEM and ERMEL publications, for instance. As regards more precisely problem solving, specific efforts have been made for clarifying the role to be given to problems at the beginning of the learning process, with a tool-object dialectics in mind. Characteristics of these have been made explicit, emphasis has been put on the devolution process, on the implicit models for action (distinguishing local and provisional students' personal procedures from the expert procedures expected at the end of the learning process), on the sharing of responsibilities between students and teacher in the management of such problems, and the importance to have students able to validate their procedures and solutions through interactions with the milieu. Several commented examples are given with numerical and geometrical goals.

The group is perfectly aware that these efforts will not be sufficient, and that the precautions taken do not guarantee adequate interpretation of the text. As pointed out by Sierpinska (2006, p. 34), there exists a universal law of the phenomenon of transposition, which she calls the radicalization law and expresses the following: "The recommendation: "do not only do $\mathrm{X}$ as you have always done; do also Y" becomes: "it is not correct to do X; it is correct to do Y"." In the case of problem solving for instance, this radicalization law can lead to the following phenomenon: the recommendation made in the syllabus to accept as correct solutions obtained through personal procedures (a requirement necessary for allowing students take some responsibility in the development of mathematics knowledge), is understood by some teachers as the obligation to give the same value to a long and poorly economic procedure (which should gradually disappear) and to an expert procedure, not encouraging students to build the mathematical knowledge aimed at. In a similar way, the reasonable desire to reach a better balance in responsibilities between the teacher and the students in the construction of new mathematical knowledge has been understood by some teachers as the necessity of giving full responsibility of this construction to the student, which is totally unrealistic, and has led to unproductive and time consuming practices.

A recent report from the General Inspection of the Ministry of Education (MEN, 2006) is devoted to the teaching of mathematics at cycle 3. It is based on observations carried out in 120 classrooms all over the country, interviews with their teachers, and analysis of the students' productions. These observations have been complemented by the reading of more than 100 reports written by inspectors after classrooms visits in 2005, and a comparison of the national evaluation tests taken by students when entering middle school in 1980, 2002 and 2005.

The report points out an evolution of the problems proposed in the national evaluation from simple problems involving multiplicative structures or proportional reasoning to more complex problems involving the reading and interpretation of data given in different forms (charts, graphical representations...). It also points out the nearly disparition of simple problems coming from daily life.

According to the inspection reports, problem-situations and research activities can be observed in classrooms, and they are not limited to the numerical domain, but it is also pointed out that about one third of the observed sessions could be improved: pedagogical differentiation is very limited, students' errors are not enough exploited, group work is often fuzzily organized and poorly productive, synthesis and institutionnalization are too much neglected.

\footnotetext{
${ }^{24}$ A recent report of the General Inspection (MEN, 2006) devoted to the teaching of mathematics in Cycle 3 points out for instance that the meaning given to primary teachers to the notion of research problem is still fuzzy, and that the way many of them use these is not fully satisfactory.
} 
From the classroom observations, the authors conclude: "In their majority, teachers implement the strategy promoted by the curriculum, and give a major role to the solving of problems. But most of them meet difficulties which lead to think that the notion of problem is blurred. Whatever be the case: problems for building new knowledge or research problems, the efforts they make are not necessarily successful. In many cases, observed practices were counter-productive, especially when they do not take into account the real state of knowledge of the students or their errors. The notions of personal procedure and expert procedure do not seem well understood. Moreover, daily life problems are given a too minor role."

Implementing in effective practices a vision of problem solving which reflects the epistemology of mathematics knowledge and benefits from the didactic knowledge which has been built along the years is definitively something difficult. The history we have described and analysed in this text lets us think that, as is the case for us as learners, there is for educational systems some kind of zone of proximal development, and that for thinking curricular changes we have to take it into consideration, in the same way we have to try to move it through research, through improved links between research and practice, and last but not least through teacher training.

\section{References}

Arsac, G., Germain, G., \& Mante, M. (1988). Problème ouvert et situation problème. Lyon: IREM de Lyon.

Balmes, R.M., \& Coppé, S. (1999). Les activités d'aide à la résolution de problèmes dans les manuels de cycle 3. Grand N, 63. 39-58.

Berthelot, R., \& Salin, M.H. (1998). The role of pupils' spatial knowledge in the elementary teaching of geometry. In D. Villani (Ed.), Perspectives on the Teaching of Geometry for the $21^{\text {st }}$ Century (pp. 71-78). New ICMI Study Series 5, Dordrecht: Kluwer Academic Publishers. Bonafé, F., Chevalier, A., Combes, M.C., Deville, A., Dray, L., Robert, J.P., \& Sauter, M. (2002). Les narrations de recherche : de l'école primaire au lycée. IREM de Montpellier and APMEP.

Bosch, M. Fonseca, C., Gascón, J. (2004). Incompletitud de las organizaciones matematicas locales en las instituciones escolares. Recherches en Didactique des mathématiques. 24/2.3, 205-250.

Bosch, M., Chevallard, Y., \& Gascón, J. (2005). Science or Magic ? The Use of Models and Theories in Didactics of Mathematics. In M. Bosch (Ed.) Proceedings of the IVth Congress of the European Society for Research in Mathematics Education (CERME 4) (pp. 1254-1263). Barcelona: Universitat Ramon Llull Editions.

Bosch M, \& Gascón, J. (2005). La praxéologie comme unité d'analyse des processus didactiques. In Mercier A. \& Margolinas C. (eds) Balises pour la didactique des mathématiques. Grenoble : La Pensée Sauvage. 107-122.

Bosch M, \& Gascón, J. (2006) Twenty-five Years of the Didactic Transposition. ICMI Bulletin $\mathrm{n}^{\circ} 58$, 51-65. http://www.mathunion.org/ICMI/bulletin/

Brousseau, N., \& Brousseau, G. (1987). Rationnels et décimaux dans la scolarité obligatoire. IREM de Bordeaux.

Brousseau, G. (1997). Theory of Didactical Situations in Mathematics (1970-1990). Dordrecht: Kluwer Academic Publishers.

Brousseau, G. (2006). Mathematics, Didactical Engineering and Observation. Lecture presented at the PME 30 Conference, Prague, July 2006. Retrieved from http://www.math.washington.edu/ warfield/Didactique.html

Chevalier, A., \& Sauter, M. (1992). Narration de recherche. IREM de Montpellier. 
Chevallard, Y. (1985). La transposition didactique (1991) Grenoble : La Pensée Sauvage.

Chevallard, Y. (1992). Concepts fondamentaux de la didactique. Perspectives apportées par une approche anthropologique. Recherches en Didactique des mathématiques. 12/1. 73-112. Chevallard, Y. (1999). L'analyse des pratiques enseignantes en théorie anthropologique du didactique. Recherches en Didactique des mathématiques, 19/2, 221-266.

Chevallard, Y. (2002). Organiser l'étude. Cours 1 - Structures \& Fonctions. Cours 3 Écologie \& Régulation. In J.L. Dorier \& al. (Eds) Actes de la XI ${ }^{\text {ème }}$ École d'été de Didactique des Mathématiques (pp. 3-22 \& 41-56). Grenoble: La Pensée Sauvage.

Chevallard, Y. (2006). Steps towards a new epistemology in mathematics education. In M. Bosch (Ed.) Proceedings of the IVth Congress of the European Society for Research in Mathematics Education (CERME 4) (pp. 22-30). Barcelona: Universitat Ramon Llull Editions.

Commission Inter-IREM Premier Cycle (1986-1989). Suivis Scientifiques. Lyon : IREM de Lyon.

COPIRELEM (1987). Aides pédagogiques pour le cycle moyen. Situations problèmes. Elemmath IX. Brochure 64. Paris: APMEP.

COPIRELEM (2003). Concertum. Dix ans de formation de professeurs des écoles en mathématiques. Paris: Editions ARPEME. Contact www.arpeme.com

Dorier, J.L. (Ed.) (2000). On the teaching of linear algebra. Dordrecht: Kluwer Academic Publishers.

Douady, R. (1986). Jeux de cadre et dialectique outil-objet. Recherches en Didactique des mathématiques, 7/2, 5-32.

ERMEL (1977 to 1982). Apprentissages mathématiques à l'école élémentaire (CP to CM2). Paris: Hatier.

ERMEL (1991 to 1999). Apprentissages numériques et résolution de problèmes (CP to CM2). Paris: Hatier.

Gascón, J. (1993). Desarrollo del conocimiento matemático y analysis didáctico: del patrón de analisis-síntesis a la genesis del lenguaje algebraico. Recherches en Didactique des mathématiques, 13/3, 295-332.

Gascón, J. (1998). Evolución de la didáctica de la matemática como disciplina científica. Recherches en Didactique des mathématiques, 18/1, 7-34.

Glaeser, G. (1976). Le livre du problème. Pédagogie de l'exercice et du problème. Paris: Editions CEDIC (second edition).

Grenier, D., \& Payan, C. (1998). Spécificités de la preuve et de la modélisation en mathématiques Discrètes. Recherches en Didactique des mathématiques, 18/2, 59-100.

Grenier, D., \& Payan, C. (2002). Situations de recherche en «classe»: essais de caractérisation et propositions de modélisation. In, V. Durand-Guerrier \& C. Tisseron (Eds), Actes du séminaire national de Didactique des mathématiques 2002 (pp. 189-204). Paris: IREM Paris 7.

Houdement, C. (1999). Le choix des problèmes pour « la résolution de problèmes ». Grand N, 63, 59-76.

IREM de Lyon (1983). 250 problèmes pour nos élèves. Lyon: IREM de Lyon.

Laborde, C. \& Perrin-Glorian, M.J. (Eds). (2005). Teaching Situations as Object of Research: Empirical Studies within Theoretical Perspectives. Educational Studies in Mathematics, 59/12-3 (Special Issue).

Legrand, M. (1993). Débat scientifique en classe de mathématiques. Repères-IREM, 10, 123158.

Masselot, P. (2000). De la formation initiale en didactique des mathématiques (en centre IUFM) aux pratiques quotidiennes en classe. Thèse de Didactique des Mathématiques. Paris: Université Paris 7. 
MENJS (1991). Les cycles à l'école primaire. Paris: Hachette et CNDP.

MEN (1995). Les programmes à l'école primaire. Paris: Hachette et CNDP.

MEN (2002a). Programmes du primaire (2002). Retrieved from http://www.cndp.fr/doc_administrative/programmes/accueil.htm

MEN (2002 b). Documents d'application des programmes. Mathématiques. Cycle 2 (37 pages), Cycle 3 (47 pages). Paris: Scéren.CNDP.

MEN (2005). Documents d'accompagnement des programmes. Mathématiques. (96 pages). Paris: Scéren.CNDP.

MEN (2006). L'enseignement des mathématiques au cycle 3 de l'école primaire. Rapport à monsieur le ministre de l'éducation nationale, de l'enseignement supérieur et de la recherche. Retreived from www.education.gouv.fr/cid4172/l-enseignement-des-mathematiques-aucycle-3-de-l-ecole-primaire.html

MEN (2007) Programmes $d u$ secondaire (2002). Retrieved from http://eduscol.education.fr/D0015/LLPHPR01.htm

Ouvrier-Buffet, C. (2003). Construction de définitions / construction de concepts : vers une situation fondamentale pour la construction de définitions en mathématiques. Thèse de Didactique des Mathématiques. Grenoble: Université Joseph Fourier.

Perrin-Glorian, M.J. (1994). Théorie des Situations Didactiques : Naissance, Développement, Perspectives, In, M.Artigue \& al. (Eds), Vingt Ans de Didactique des Mathématiques en France, pp. 97-147. Grenoble: La Pensée Sauvage.

Polya, G. (1945). How to solve it? Princeton: University Press.

Robert, A., \& Robinet J.(1996). Prise en compte du méta en didactique des mathématiques. Recherches en Didactique des mathématiques, 16/2,145-176.

Robert, A., \& Rogalski, J. (2002). Le système cohérent et complexe des pratiques des enseignants de mathématiques: une double approche. Revue Canadienne de l'enseignement des sciences, des mathématiques, de la technologie, 12/4, 505-528.

Robert, A. \& Rogalski, J. (2005) A cross-analysis of the mathematics' teacher activity. An example in a French $10^{\text {th }}$-grade class. Educational Studies in Mathematics, 59/1-2-3. 259-298. Roditi, E. (2001). L'enseignement des nombres décimaux en sixième. Étude de pratiques ordinaires? Thèse de Didactique des Mathématiques. Paris: Université de Paris 7.

Rodriguez, E., Bosch, M., \& Gascón, J. (2007). An anthropological approach to metacognition: the "study and research courses". Communication to CERME 5. Retrieved from http://www.cyprusisland.com/cerme/group11.htm

Sarrazy, B. (1997). Sens et situations : une mise en question de l'enseignement des stratégies méta-cognitives en mathématiques. Recherches en Didactique des mathématiques, 17/2,135166.

Sauter, M. (2000). Formation de l'esprit scientifique avec les narrations de recherche au cycle central du collège. Repères-IREM, 39, 7-20.

Schoenfeld, A.H. (1985). Mathematical Problem Solving. Orlando: Academic Press.

Schoenfeld, A.H. (1992). Learning to think mathematically: problem solving, metacognition, and sense-making in mathematics. In D.Grouws (Ed.), Handbook for Research on Mathematics Teaching and Learning (pp. 334-370). New York: MacMillan.

Sierpinska, A. (2006). Entre l'idéal et la réalité de l'enseignement mathématique. Annales de Didactique et de Sciences Cognitives, 11, 5-40.

Verdier, J. (1986). Travail de groupe en séquences longues: démarche de recherche sur problèmes ouverts (seconde). Nancy : APMEP Lorraine.

Vergnaud, G. (1990). La théorie des champs conceptuels. Recherches en Didactique des Mathématiques, 10/2.3, 133-170.

Vergnes, D. (2001). Les effets d'un stage de formation en géométrie. Recherches en Didactique des Mathématiques. 21/1.2, 99-122. 
Warfield, V.M. (2006). Invitation to didactique. Retrieved from http://www.math.washington.edu/ warfield/Didactique.html 


\begin{tabular}{|c|c|c|c|c|}
\hline & \multicolumn{2}{|c|}{ Primary school } & \multicolumn{2}{|c|}{ Secondary school } \\
\hline $\begin{array}{l}\text { French } \\
\text { names }\end{array}$ & $\begin{array}{l}\text { École } \\
\text { cycle } 2\end{array}$ & $\begin{array}{l}\text { École } \\
\text { cycle } 3\end{array}$ & Collège & Lycée \\
\hline & $\begin{array}{c}\text { CP \& } \\
\text { CE1 }\end{array}$ & $\begin{array}{c}\text { CE2, } \\
\text { CM1 \& } \\
\text { CM2 }\end{array}$ & $\begin{array}{l}\text { 6ème to } \\
\text { 3ème }\end{array}$ & $\begin{array}{l}\text { 2nde, 1ère, } \\
\text { Terminale }\end{array}$ \\
\hline $\begin{array}{l}\text { Age of } \\
\text { students }\end{array}$ & $\begin{array}{c}\text { from } 6 \text { to } \\
8\end{array}$ & $\begin{array}{c}\text { from } 8 \text { to } \\
11\end{array}$ & $\begin{array}{c}\text { from } 11 \text { to } \\
15\end{array}$ & $\begin{array}{c}\text { from } 15 \text { to } \\
18\end{array}$ \\
\hline $\begin{array}{l}\text { Equivalent } \\
\text { in grade }\end{array}$ & $1^{\text {st }}$ to $2^{\text {nd }}$ & $3^{\text {rd }}$ to $5^{\text {th }}$ & $6^{\text {th }}$ to $9^{\text {th }}$ & $10^{\text {th }}$ to $12^{\text {th }}$ \\
\hline
\end{tabular}

Table 1: Structure of primary and secondary general education in France ${ }^{25}$

\footnotetext{
${ }^{25}$ The table does not incorporate vocational high schools (Lycées professionnels) that offer two successive two years programs leading to the BEP and then the vocational Baccalaureat from grade 10, and are parallel to the Lycée.
} 


\section{Appendix}

Appendix 1 Les maths à la découverte du monde CE1- Student worksheet - Éditions Hachette 2004. Page 96.

From sums to products: multiplication

Observe how the number of mail bags is computed and do the same with the trucks.

Objectifs : Savoir transformer une

somme en produit et inversement.

Reconnaître dans un arrangement

d'objets une situation multiplicative.

Calcul mental : Donner un nombre

$(<6)$. Calculer 2 fois, 3 fois, 4 fois,

5 fois ce nombre par additions succes-

sives $(3$ fois $4 \rightarrow 4+4 \rightarrow 8+4 \rightarrow 12$ ).

Observe le calcul du nombre de sacs de courrier transportés par les voitures.

Fais la même chose avec les camions.

\section{De la somme au produit : la multiplication}

Comment simplifier les écritures mathématiques ?
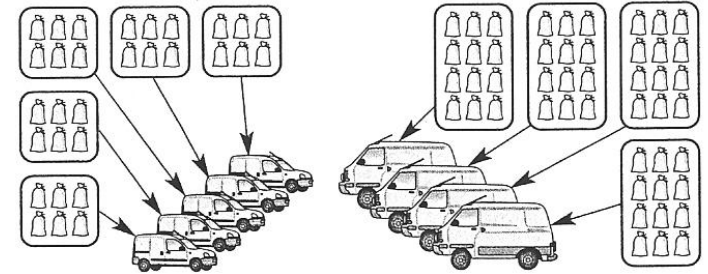

Retiens bien

Tu peux remplacer une addition de nombres égaux par une multiplication.

5 voitures transportent 6 sacs chacune.

Nombre de sacs : $6+6+6+6+6=30$

$$
\text { Ou : } 6 \times 5
$$

On dit 6 multiplié par 5 ou 5 fois 6 . sacs chacun.

Nombre de sacs :

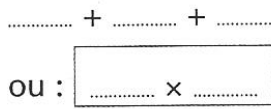

On dit multiplié par ou fois

1 Écris les nombres de timbres sous forme d'une addition, puis d'une multiplication.

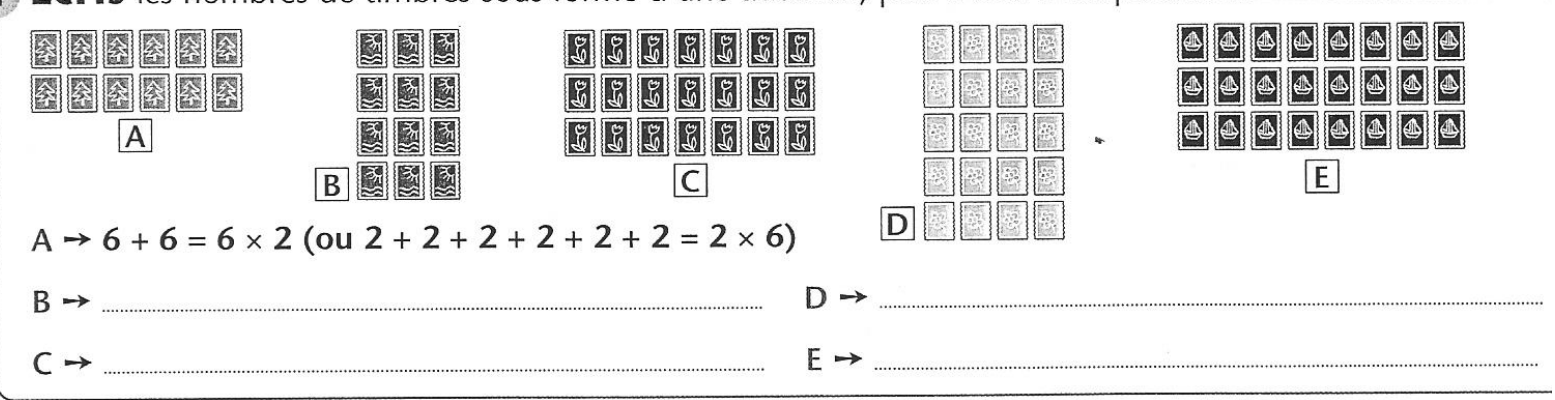

2 Transforme ces additions en multiplications (quand c'est possible).

$5+5+5+5+5=$

$21+21+21+21=$

3 Transforme ces multiplications en additions.

$6 \times 3=$

$3 \times 6=$

$23 \times 3=$

$100 \times 4=$
$12+12+12=$

$7+7+7+7=$
$8+8+8+8+8+6=$

$10+10+10+10=$
Le soin du malin

Oscar compte les timbres ligne par ligne. II écrit :

$3+3+3+3+3+3+3+3+3=3 \times 9$

Simplifie son travail en comptant colonne par colonne. 
Appendix 2 : EuroMaths CE1 - Student textbook. Éditions Hatier 2001. Page 86

Rules for the game: three players. Each player randomly chooses a grid, throws the die and colours the number of rows given by the die. The player who has coloured the biggest number of squares wins 1 point. Players play 5 successive games.

\section{C.3 Multiplication (1)}

- Activité préparatoire : Le jeu des carreaux colorés.

\section{Application}

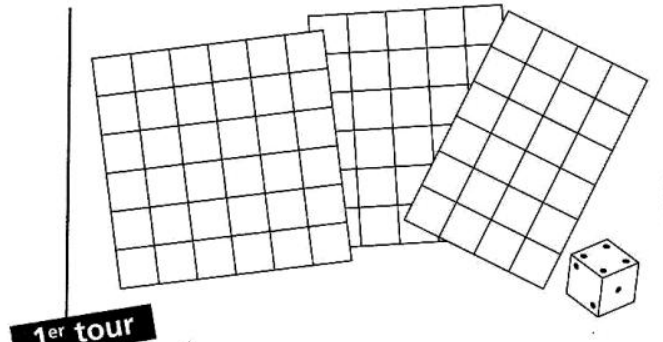

Marie a tiré une grille de 4, elle fait 5 avec le dé. Audrey a tiré une grille de 5 , elle fait 6 avec le dé. José a tiré une grille de 6 , il fait 3 avec le dé. Colorie les grilles d'Audrey et de José.

Qui marque 1 point?

\section{$2^{\text {e tour }}$}

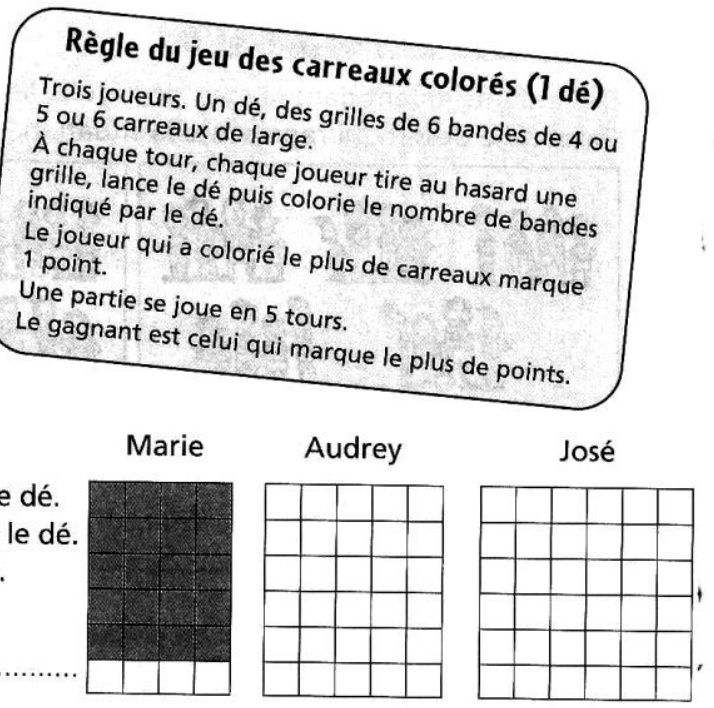

Marie a tiré une grille de 6 , elle fait 4 avec le dé. Audrey a tiré une grille de 5 , elle fait 5 avec le dé. José a tiré une grille de 4 , il fait 6 avec le dé.

Qui marque 1 point?

Écris les calculs que tu fais

\section{Exercices}

1. Audrey calcule le nombre de carreaux colorés par ses camarades au $3^{\mathrm{e}}$ tour. Aide-la à terminer ses calculs.

Marie: $4+4+4+4=$

Audrey: $5+5+5=$

José : $6+6+6+6+6=\ldots$.
Voici ce que José a noté au $4^{\mathrm{e}}$ tour. Complète le tableau.

\begin{tabular}{|l|c|c|c|}
\cline { 2 - 4 } \multicolumn{1}{c|}{} & $\begin{array}{c}\text { Type } \\
\text { de grille }\end{array}$ & $\begin{array}{c}\text { Nombre } \\
\text { sur le dé }\end{array}$ & $\begin{array}{c}\text { Nombre de } \\
\text { carreaux colorés }\end{array}$ \\
\hline Marie & 5 & 4 & \\
\hline Audrey & 6 & 2 & \\
\hline José & 4 & 5 & \\
\hline
\end{tabular}

Avec sa grille de 4, Marie a lancé le dé. Elle a colorié 12 cases. Que marquait le dé?

- Objectif • Résoudre des problèmes d'addition réitérée.
- Mise en route - Jeu du furet : les enfants comptent de 5 en 5 a partir de 0 en croissant, et à partir de 50 en décroissant. Les enfants comptent de 2 en 2 à partir de 0 en croissant, et à partir de 40 en décroissant. Reprendre plusieurs fois toujours dans le même champ numérique. 